\title{
Double trouble: preseptal cellulitis due to two species with multidrug resistance
}

\author{
Muhammad Naeem", Nasir Ali Rahimnajjad ${ }^{1}$, Irfan Majeed ${ }^{1}$ and Khalid Mahmood²
}

\begin{abstract}
A 2 Year old boy presented with painful ballooning of both eyes with the 2 days history of trauma to the head while playing. His vaccination was complete. On examination he was afebrile. The Eyes were ballooned with blackish crust over both lids. On local examination, eye swelling was tense with severe tenderness. The diagnosis of Preseptal cellulitis was made. We did an Emergency drainage and pus was sent for culture that came out to be positive for Pseudomonas aeruginosa and Proteus mirabilis with multiple drug resistance. The coverage was given by Imipenem + cilastatin and child had wonderful recovery.
\end{abstract}

\section{Letter to the Editor}

A 2 Year old boy presented with painful ballooning of both eyes with the 2 days history of trauma to the head while playing. His complete history reveals unremarkable antenatal, natal and postnatal history. He was afebrile on presentation. His vaccination was complete according to EPI schedule. The past history was significant for sinusitis for which he got the treatment (undocumented). On examination the patient was afebrile with dry cough and vitally stable. The Eyes were ballooned with blackish crust over both lids (Figure 1). On local examination, eye swelling was tense with severe tenderness. His blood work up was normal except raised leukocyte count with left shift (might be due to infection). The diagnosis of pre-septal cellulitis was made after excluding other possible causes clinically and radiologically and antibiotic was empirically started (amoxicillin + clavulinic acid) after both eyes were drained and pus was sent for culture and sensitivity, the culture report came out to be positive for Pseudomonas aeruginosa and Proteus mirabilis with multiple drug resistance (Table 1). As indicated in the antibiogram, the coverage was given by Imipenem + cilastatin $(15 / 15 \mathrm{mg} / \mathrm{kg} /$ dose every 6 hours $)$ because it was the only drug to which both bacteria were sensitive. The child had wonderful recovery after the treatment. Written informed consent was obtained from the patient's parents for the publication of this report and any accompanying images.

Preseptal cellulitis is characterized by hyperemic skin and eyelid distension without the obvious signs of orbital congestion [1]. Preseptal cellulitis can occur as a result of exogenous as well as endogenous extension [2]. In this particular case the rare combine infection by two bacteria with multi drug resistance made this case interesting and

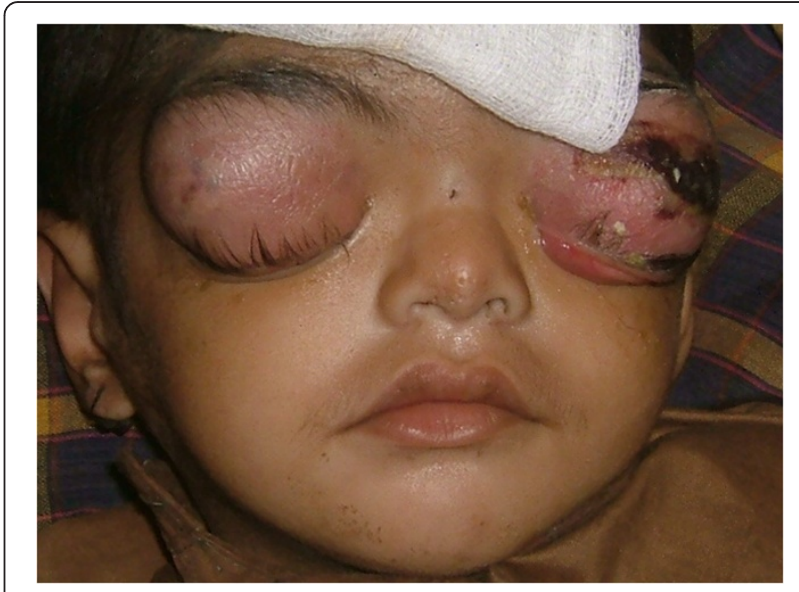

Figure 1 Photograph showing the patient's eyes with preseptal cellulitis.

\footnotetext{
* Correspondence: dowgrad2012@yahoo.com

${ }^{1}$ Interns, Dow Medical College, Dow University of Health Sciences, Karachi, Pakistan

Full list of author information is available at the end of the article
} 
Table 1 Resistance antibiogram

\begin{tabular}{llll}
\hline S. no & Antibiotic & $\begin{array}{l}\text { Sensitivity } \\
\text { patterns } \\
\text { Pseudomonas } \\
\text { aeruginosa }\end{array}$ & $\begin{array}{l}\text { Proteus } \\
\text { mirabilis }\end{array}$ \\
\hline $\mathbf{1 -}$ & Ampicillin & $\mathrm{R}$ & $\mathrm{R}$ \\
$\mathbf{2 -}$ & Co-amoxiclav & $\mathrm{R}$ & $\mathrm{R}$ \\
$\mathbf{3 -}$ & Imipenem \& Cilastatin & $\mathrm{S}$ & $\mathrm{S}$ \\
$\mathbf{4 -}$ & Cefixime & $\mathrm{R}$ & $\mathrm{R}$ \\
$\mathbf{5 -}$ & Ceftriaxone & $\mathrm{R}$ & $\mathrm{R}$ \\
$\mathbf{6 -}$ & Ceftazidime & $\mathrm{S}$ & $\mathrm{R}$ \\
$\mathbf{7 -}$ & Cefuroxime & $\mathrm{R}$ & $\mathrm{S}$ \\
$\mathbf{8 -}$ & Norfloxacin & $\mathrm{R}$ & $\mathrm{R}$ \\
$\mathbf{9 -}$ & Ciprofloxacin & $\mathrm{S}$ & $\mathrm{R}$ \\
$\mathbf{1 0 -}$ & Levofloxacin & $\mathrm{S}$ & $\mathrm{R}$ \\
$\mathbf{1 1 -}$ & Gentamicin & $\mathrm{R}$ & $\mathrm{R}$ \\
$\mathbf{1 2 -}$ & Tobramycin & $\mathrm{S}$ & $\mathrm{R}$ \\
\hline
\end{tabular}

\section{$\mathrm{R}=$ Resistant.}

$\mathrm{S}=$ sensitive.

difficult to manage. This infection can progress to involve the post-septal space and result in orbital cellulitis with life threatening complications. Majority of the cases are caused by Streptococci or Staphylococci [3]. While making diagnosis, this condition should be differentiated from other causes of Eye swelling ranging from simple inflammation to life threatening Retinoblastoma [4]. Once this diagnosis is suspected it should be related with lab investigations like complete blood count, blood culture and culture of aspirate so that therapy should be targeted [5]. Computed Tomography is recommended investigation to delineate the extension of the cellulitis [6]; however, is not necessary. Nasal decongestants are recommended if sinusitis is suspected and antibiotics should be continued from three to ten days depending on severity of the infection.

Vision is the most wonderful sense gifted by nature and restoration of vision after such sinister infection was the source of joy both for family and doctors.

\section{Competing interests}

The authors state that they have no competing interest.

\section{Authors' contribution}

MN and NAR: literature search and conception. IM and NAR: Initial draft preparation. KM and MN: Finalization of the draft. Picture and Informed Consent taken: MN. Informed Written consent was taken for the publication of the picture. All authors read and approved the final manuscript.

\section{Author details}

IInterns, Dow Medical College, Dow University of Health Sciences, Karachi, Pakistan. ${ }^{2}$ Professor and Chief, Department of Internal Medicine, Dow Medical College, Dow University of Health Sciences Karachi, Karachi, Pakistan.

Received: 22 August 2012 Accepted: 25 June 2013

Published: 26 June 2013

\section{References}

1. Jones DB, Steinkuller PG: Strategies for the initial management of acute preseptal and orbital cellulitis. Tr Am Ophth Soc 1988, 86:94-112.

2. Drummond SR, Diaper CJM: Chlamydial conjunctivitis presenting as pre septal cellulitis. Head Face Med 2007, 3:16.

3. Nageswaran S, Woods CR, Benjamin DK Jr, Givner LB, Shetty AK: Orbital cellulitis in children. Pediatr Infect Dis J 2006, 25:695-699.

4. Gonzalez MO, Durairaj VD: Understanding pediatric bacterial preseptal and orbital cellulitis. Middle East Afr J Ophthalmol 2010, 17(2):134-137.

5. Ambati BK, Ambati J, Azar N, Stratton L, Schmidt EV: Periorbital and orbital cellulitis before and after the advent of haemophilus influenzae type B vaccination. Ophthalmology 2000, 107:1450-1453.

6. Eustis HS, Mafee MF, Walton C, Mondonca J: MR imaging and CT of orbital infections and complications in acute rhinosinusitis. Radiol Clin North Am 1998, 36:1165-1183.

doi:10.1186/1746-160X-9-17

Cite this article as: Naeem et al:: Double trouble: preseptal cellulitis due to two species with multidrug resistance. Head \& Face Medicine 2013 9:17.

\section{Submit your next manuscript to BioMed Central and take full advantage of:}

- Convenient online submission

- Thorough peer review

- No space constraints or color figure charges

- Immediate publication on acceptance

- Inclusion in PubMed, CAS, Scopus and Google Scholar

- Research which is freely available for redistribution 